\title{
Secondary School Students' Participation in Sports and their Parents' Level of Support: A Qualitative Study
}
Authors' contribution:
A) conception and design of the study
B) acquisition of data
C) analysis and interpretation of data
D) manuscript preparation
E) obtaining funding

Vegneskumar Maniam

University of New England, Australia

\begin{abstract}
The study investigated student involvement in sports as part of co-curricular activities in the school and outside, and the effect of parental support upon their child's participation in sport. The purpose of the study was to investigate in-depth the views of year 11 students from six Australian schools about their parents' influence on their participation in sport. The schools agreed to allow their students to participate on a voluntary basis. The primary data were gathered from 111 students in the form of written personal statements in response to the researcher's open-ended guideline questions, based on the humanistic sociological approach of studying respondents' personal perspectives on a particular phenomenon. The $80 \%$ of respondents who claimed to play sport were involved in a total of 23 different sports, with soccer being the most frequently mentioned (29\%). The $20 \%$ of respondents who did not play sport all attended schools where participation in sport was not compulsory. Parental support for sports participation was evident in $89 \%$ of their comments, but only $11 \%$ of parents played an active role. The negative family constraints identified by $15 \%$ of respondents referred to issues such as lack of parental interest in sport, concerns about safety, maintaining a balance between sport and other areas of life, and the cost involved
\end{abstract}

sports, secondary school students, parental support

Australia is a nation well known for its participation and involvement in international sporting events (Currie 2009). Community participation in sports and recreational activities has also been recognised as an important feature of the Australian way of life (Independent Sport Panel 2009). Yet concern has been increasingly expressed at the decline in young people's participation in sport (Independent Sport Panel 2009) and the fact that non-participation is often related to gender, socio-economic and geographic location subgroups in society (Office for Recreation and Sport 2010), as well as minority ethnic background (Taylor 2000).

Recent Australian Bureau of Statistics (Australian Bureau of Statistics 2012) studies on participation of Australian youth in sports and cultural activities (drama/dance) indicated that overall, $40 \%$ of young adolescents aged 15 years and over did not participate in sporting or cultural activities. This lack of participation rose to $36 \%$ for those in one-parent families; to $44 \%$ for those from non-English speaking 
countries; and to $49 \%$ for those with unemployed parents. According to the study walking for exercise (19\%) was the most popular physical activity, and was more popular among females $(25 \%)$ compared to their male counterparts (14\%). Males were more likely to play golf $(6.6 \%)$ and to participate in cycling $(8.5 \%)$ and BMXing (4.0\%) respectively. The only available South Australian figures show $61 \%$ of urban secondary boys and $70 \%$ of urban secondary girls played school-based sports. Among primary and secondary students combined, 13\% played soccer, 12\% netball, 11\% Australian Rules Football and basketball, and 8\% cricket (Office for Recreation and Sport 2010).

A study by Wheeler (2011), on 'family culture for sports participation highlighted some interesting findings related to parental support. The study showed that parents' support for their children's sports participation was related to their child's enjoyment and the opportunity for keeping fit and healthy. Parents also believed participation in sports would provide their children with the opportunity for making new friends, socializing and encouraging their future sports participation. Another finding revealed that parents, who were actively involved in sports and physical activities, are more inclined to support their children's sporting involvement. Wheeler also discussed the positive affects of sports participation on parents and children's relationships. The majority of the parents in the study believed that through sports their relationship with their child became stronger.

At the same time, the study highlighted some of the negative aspects related to parents' involvement in their children's sports participation. Financial issues related to children's sports participation was highlighted in another study conducted in Iran. The study found a strong correlation between parents' socio-economic status and children's sports participation. Financial issues were of concern to some parents whose resources could not support their children's participation in expensive sports. The higher the parent's income the more likely it was that the children were participating in sport (Nezhad, Rahmati, \& Nezhad 2012). The Iranian parents were also concerned about their own level of understanding, skills and ability in the particular sport their child chose to play. These were the main negative issues identified in relation to parents' involvement in their children's sports.

Family socio-economic status also appears to be a critical influence on secondary students' participation in sports. Findings by (Wright, MacDonald, \& Groom 2003), show that sport and physical activity tend not to be important to low socio-economic families where concern for adequate food and clothing take priority. At the other end of the scale, children from high socio-economic families are often constrained to sports that contribute to the ethos of their school and produce the right kind of attributes (Wright et al. 2003).

Beside school teachers, peers, coaches and club sport administrators, it is generally regarded that parents have considerable impact on students' involvement in sport (Griffin 1998). Elite level athletes frequently cite the role of parents in fostering their sport participation (Lee 2009). A qualitative study carried out by Leff and Hoyle (1995), focusing on junior tennis players in the United States, found that the players' statements acknowledged the benefit of parental encouragement. Parents have also been shown to have a modelling effect on their child's participation through their own sporting activity. Parents' levels of sporting activity have been found to be among the strongest determinants of their child's activity patterns. In such families the children were 5.8 times as likely to be active than those with non-active parents (Moore, Lombardi, et al.1991).

Another study in Australia investigated parental perceptions on what are the main barriers, which prevented their children's participation in organised sport. Although this particular study focused on children aged between 5 to 14 years old, but some of the findings were relevant to this paper. For example the barriers mentioned most of often by the parents in this study related to cost, time and travel factors as well as the number of sports their children were playing. They also reported that the parent's decision were influenced by other factors, particularly their child's own interest, which most considered the most important factor influencing their children's involvement in sports (Hardy, Kelly, et al. 2010).

A Victorian qualitative study of students' parents (Hesketh, Waters, et al. 2005) yielded parental comments on the value of role-modelling healthy behaviours, including physical activity. Brusted (1993) also reported a positive relationship between higher parental encouragement and greater perceived physical competence for children. If the parents were actively involved in sporting activities then it was also likely that 
the children would develop positive attitudes towards sports and be actively involved in more physical activities (Cote 1999).

Another American study by Fredrick and Eccles, 2004 on 'Parental Influences on Youth Involvement in Sports' which discussed various issues related to parents as role models, parent's beliefs, values and expectations. The discussion also highlighted the importance of parental encouragement in supporting kids' sports involvement especially for girls' participation in sports. The study also considered gender differences in sports participation. The study indicated that parents often provided different treatment for sports participation between boys and girls.

A study conducted in the United Kingdom among 40816 year old swimmers indicated that parents, especially mothers' social influence was stronger in their participation in swimming. The study also discussed that the role of parents are more important in the childhood stage compared to adolescent stage, especially in the context of mother. Father's role was more of a supportive role compared to mother who played a major role in organizing adolescent's involvement in swimming. There were other influences like coaches and peers also involved in adolescents' swimming participation (Chan, Lonsdale, \& Fung 2012).

These previous studies point to the need for an in depth qualitative study to investigate parent's beliefs and behaviours related to children's sports participation.

This study set out to examine the students' views regarding their parents' influence on their sports participation. This is important for better understanding of the participation and non-participation of secondary school students in sport.

\section{Method \\ Participants}

The participants were 111 Year 11 students drawn from six metropolitan co-educational schools in South Australia. Because the schools selected the students or class group to take part, the numbers differed from school to school, depending on class sizes and the availability of students on the day of data collection. Of the 111 students involved, $70 \%$ were aged 16 and $40 \%$ were female.

\section{Research design}

The research was designed to investigate whether or not respondents participated in sports and how far family and school factors influenced this participation. The qualitative self- evaluated data were written in response to open-ended questions designed by the researcher. This paper examines the responses of the 111 students view, detailing what their parents influence on their sports participation. As qualitative research, it was focused on the views of these particular respondents and there was no intention to generalize the findings to a larger population. Some indication of the authenticity of the students' views was provided by the comparatively large number of respondents and the consistency of views expressed across the six schools.

\section{Measures}

Qualitative studies such as this depend mainly on interpreting the spoken or written words of the respondents in terms of their psychological or cultural meanings rather than statistical analysis of numerical measures. The humanistic sociological approach stresses the interpretation of data from the perspective of the participants as social and cultural beings (Smolicz \& Secombe 1981, 1986, 1989). The different types of parental influence identified were categorized thematically using NVIVO software and plotted against one of the key social and cultural groups to which the respondents belonged, the school. Frequency tables - one for those respondents who played sport and a separate one for those who did not - were constructed to show the distribution of the categorized responses across the six school groupings. Percentages were given in the totals columns, where the numbers were high enough to justify this calculation. 


\section{Procedure}

Once this research project had been granted ethics approval from the University of Adelaide and the Department of Education \& Children's Services, a formal invitation letter with documentation about the research proposal was sent to principals of Adelaide secondary schools across all three sectors. Entry to each school was negotiated through the six principals who agreed to participate. The year 11 class of respondents was selected by the school, which took account of students' willingness to answer the personal statement questions. The size of the group responding was in part dependent on the number of students present on the day when the personal statements were collected. One period of normal lesson time (not physical education) was devoted to completing the questions.

\section{Results}

The extent of sports participation among the respondents and the most frequently played sports are presented in Table 1, which shows the frequency of responses for each school, as well as the totals. Overall 89 $(80 \%)$ of the 111 respondents indicated that they played one or more sports; the other $22(20 \%)$ were not involved in any sport. The total of 179 mentions of sports played was twice the number of students playing sport, but the mentions ranged from 5 in School S (which had the highest number of students not participating in sports) to 44 in School P.

Table 1. Respondents' Sports Participation

\begin{tabular}{|c|c|c|c|c|c|c|c|c|}
\hline $\begin{array}{l}\text { Schools } \\
\text { Sport }\end{array}$ & $\begin{array}{l}\mathrm{B} \\
\mathrm{N}=17\end{array}$ & $\begin{array}{l}C \\
N=16\end{array}$ & $\begin{array}{l}\mathrm{H} \\
\mathrm{N}=\mathbf{2 5}\end{array}$ & $\begin{array}{l}P \\
N=18\end{array}$ & $\begin{array}{l}S \\
N=13\end{array}$ & $\begin{array}{l}\mathrm{Z} \\
\mathrm{N}=22\end{array}$ & $\begin{array}{l}\text { Total } \\
\text { N=111 }\end{array}$ & $\begin{array}{l}\text { \% of } \\
111\end{array}$ \\
\hline Soccer & 8 & 5 & 2 & 10 & 2 & 5 & 32 & $29 \%$ \\
\hline $\begin{array}{l}\text { Australian Rules } \\
\text { Football }\end{array}$ & 3 & 3 & 6 & 2 & 2 & 5 & 21 & $19 \%$ \\
\hline Tennis & 5 & 3 & 4 & 5 & 0 & 1 & 18 & $16 \%$ \\
\hline Netball & 2 & 1 & 6 & 5 & 0 & 2 & 16 & $14 \%$ \\
\hline Basketball & 3 & 3 & 1 & 5 & 0 & 3 & 15 & $13 \%$ \\
\hline Volleyball & 2 & 6 & 2 & 3 & 1 & 1 & 15 & $13 \%$ \\
\hline Swimming & 3 & 1 & 2 & 2 & 0 & 2 & 10 & $9 \%$ \\
\hline Athletics & 2 & 2 & 5 & 1 & 0 & 0 & 10 & $9 \%$ \\
\hline Cricket & 1 & 0 & 2 & 3 & 0 & 1 & 7 & $6 \%$ \\
\hline 14 Other Sports & 5 & 7 & 10 & 8 & 0 & 5 & 35 & $31 \%$ \\
\hline $\begin{array}{l}\text { Mentions of } \\
\text { Sports Played }\end{array}$ & 33 & 31 & 40 & 44 & 5 & 25 & 179 & 159 \\
\hline Participants & 17 & 16 & 19 & 18 & 4 & 15 & 98 & $80 \%$ \\
\hline Non Participants & 0 & 0 & 6 & 0 & 9 & 7 & 22 & $20 \%$ \\
\hline
\end{tabular}

Source: own study.

Note. The total mentions of sports played is greater than the number of respondents $(\mathrm{N}=111)$, and the percentage therefore over 100, because some respondents named two or more sports.

Among the 23 sports named, soccer was the most popular, but played by only 32 respondents (29\%). Australian Rules Football was mentioned by 21 students (19\%), but cricket by only 7 (6\%). The 16 female respondents who said they played netball represented $14 \%$ of the total, but $36 \%$ of the girls. The 14 least frequently mentioned sports have been grouped together since each attracted only one or two participants. Yet overall these 14 sports accounted for over a third $(\mathrm{N}=35)$ of the 89 students who played sport.

The comments on what their family thought about sport were read closely to identify different types of family influence. It was evident that these fell under two main headings: positive support and what could be called negative constraints. Five types of positive parental support were identified, along with seven types of negative parental constraint.

Table 2 presents the five types of parental support identified, together with illustrative examples of each form of support, taken directly from the respondents' statements. The citations are quoted verbatim and sometimes contain errors of grammar, punctuation and spelling. Words or punctuation in square brackets are used where these are considered necessary for clear understanding. 
Table 2. Types of Positive Parental Support Derived from Respondents' Comments

\begin{tabular}{|c|c|}
\hline Positive Support & Example of respondent's comments \\
\hline $\begin{array}{l}\text { Support and } \\
\text { Encouragement }\end{array}$ & $\begin{array}{l}\text { - They like me playing sport and } \\
\text { encourage it. } \\
\text { - My mum and dad are very supportive of } \\
\text { me playing sport. } \\
\text { - My mum, dad are both right behind my } \\
\text { involvement in sport. } \\
\text { - They encourage me a lot and are very } \\
\text { happy for me... } \\
\text { - My family encourage [me] to play a lot } \\
\text { of sports because ... it's good } \\
\text { for me and I enjoy it. }\end{array}$ \\
\hline Parents feeling proud & $\begin{array}{l}\text { - } \quad \text { very supportive, proud. } \\
\text { - } \quad \text { they are very proud of my achievement. } \\
\text { - } \quad \text { They are very proud of me. }\end{array}$ \\
\hline $\begin{array}{l}\text { Parental involvement } \\
\text { in their children's sports }\end{array}$ & 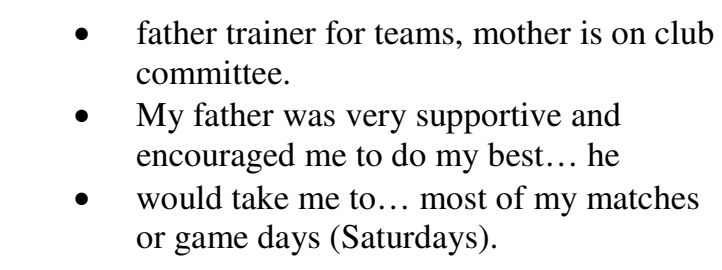 \\
\hline $\begin{array}{l}\text { Family members who } \\
\text { were actively involved } \\
\text { in sports }\end{array}$ & $\begin{array}{l}\text { - My family plays cricket [and] football so } \\
\text { - M do it as well. } \\
\text { - } \text { just a nomily all play different sports so it's } \\
\text { My dad and his side of the family are all } \\
\text { very fit and active most of his family } \\
\text { have won the [Bay Sheffield]. They are } \\
\text { very much runners. My mum keeps fit } \\
\text { and when she was young she was very } \\
\text { involved in different sports. My older } \\
\text { sister is a personal trainer and likes it } \\
\text { very much. My younger brother play for } \\
\text { about } 4 \text { football clubs and plays state } \\
\text { football. }\end{array}$ \\
\hline $\begin{array}{l}\text { Parents involved in } \\
\text { sport as the coach of } \\
\text { their team }\end{array}$ & $\begin{array}{l}\text { - My mum has coached me in both school } \\
\text { and club for a lot of my netball life. }\end{array}$ \\
\hline
\end{tabular}

Source: own study.

In the same way, Table 3 presents seven types of negative parental constraints, with illustrative comments provided by the respondents. A number of these examples demonstrate that comments which were classified as negative constraints for the purpose of this analysis were often in the form of qualified support for their children's participation in sport rather than outright opposition to it. 
Table 3. Types of Negative Constraint derived from Respondents' Comments

\begin{tabular}{lcl}
\hline Negative Constraint & Example of respondent's comments \\
\hline $\begin{array}{l}\text { Pressure to } \\
\text { Perform }\end{array}$ & $\bullet$ & Both parents think I should do more of it. \\
$\begin{array}{l}\text { Study more } \\
\text { important }\end{array}$ & $\bullet$ & $\begin{array}{l}\text { They like me continuing sports as a fitness purpose but they still want } \\
\text { me to take my studies at a higher priority as it is more important for my } \\
\text { future right. } \\
\text { They don't mind me doing it but they want me to take school first. }\end{array}$ \\
& $\bullet$
\end{tabular}

Safety Concerns

- They all agree with that except if it is dangerous

- They really want me to play sports but also tell me not to get injured.

Time Consuming

- They think it's excellent but sometimes they think I play too much my whole family is very sporty.

- They think it's good to play lots of sport so long as it doesn't take over my life eg [sic] school and mates. They support me lots.

Little or no interest in sport
- We aren't particularly sporty family but my family supports me in whatever I chose to do. They encourage my involvement.

- They don't play or follow any sports.

- ... my mum thinks playing sport joining a team is costly which puts her off the idea a bit if [it's] really expensive.

Source: own study

The frequency of these comments in total and across the school grouping is presented in Table 4A for students who participated in sport and in Table 4B for those students who played no sport.

Among the students who participated in sport, there were 87 comments ( $86 \%$ of the total comments) which could be classified as positive parental support, as against $11(11 \%)$ which could be interpreted as negative constraints. However, 15 of the students who played sport provided no comment on what their parents felt about their participation. The type of parental influence most frequently mentioned (51\% of the total comments) was support and encouragement for their children's participation in sport. Another $12 \%$ of comments mentioned parents' feelings of pride and approval. Only 23\% of the comments reported parents as being involved in their children's sport, with $8 \%$ of comments describing the influence of the whole family being involved in sport and an additional 3\% specifically mentioning the role of coach. The negative constraints from parents mentioned by the students included pressure to perform well in sport, reported in $3 \%$ of comments, and parental insistence that study was more important, mentioned in another 3\%. A further $2 \%$ of comments reported parental concerns about safety in sport. One parent considered sport too time consuming; another thought it limited friendships, whilst a third was reported as having little interest in sport. 
Table 4A. Family Support Reported by Students Participating in Sport

\begin{tabular}{|c|c|c|c|c|c|c|c|c|c|}
\hline \multicolumn{2}{|c|}{$\begin{array}{l}\text { Schools } \\
\text { Parents } \\
\text { Influence }\end{array}$} & $\begin{array}{l}\mathrm{B} \\
\mathrm{N}=17\end{array}$ & $\begin{array}{l}\mathrm{C} \\
\mathrm{N}=16\end{array}$ & $\begin{array}{l}\mathrm{H} \\
\mathrm{N}=18\end{array}$ & $\begin{array}{l}P \\
N=18\end{array}$ & $\begin{array}{l}S \\
N=6\end{array}$ & $\begin{array}{l}Z \\
N=14\end{array}$ & $\begin{array}{l}\text { Tota } \\
1 \\
N=8 \\
9\end{array}$ & $\begin{array}{l}\text { \% Total } \\
\text { Comments }\end{array}$ \\
\hline \multirow{5}{*}{ 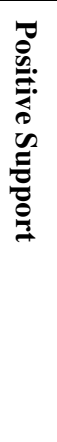 } & $\begin{array}{l}\text { Support \& } \\
\text { Encouragem } \\
\text { ent }\end{array}$ & 11 & 6 & 12 & 11 & 4 & 6 & 50 & 51 \\
\hline & $\begin{array}{l}\text { Parental } \\
\text { Involvement }\end{array}$ & 4 & 3 & 2 & 1 & 1 & 1 & 12 & 12 \\
\hline & $\begin{array}{l}\text { Approve feel } \\
\text { proud }\end{array}$ & 0 & 2 & 5 & 3 & 1 & 1 & 12 & 12 \\
\hline & $\begin{array}{l}\text { Whole } \\
\text { Family } \\
\text { Involvement }\end{array}$ & 2 & 1 & 3 & 1 & 0 & 1 & 8 & 8 \\
\hline & $\begin{array}{l}\text { Parent as } \\
\text { coach }\end{array}$ & 1 & 1 & 0 & 1 & 0 & 0 & 3 & 3 \\
\hline \multicolumn{2}{|c|}{ Sub-Total } & 18 & 13 & 22 & 19 & 6 & 9 & 87 & 86 \\
\hline \multirow{7}{*}{ 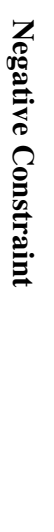 } & $\begin{array}{l}\text { Pressure to } \\
\text { Perform }\end{array}$ & 0 & 1 & 1 & 0 & 0 & 1 & 3 & 3 \\
\hline & $\begin{array}{l}\text { Study more } \\
\text { important }\end{array}$ & 1 & 2 & 0 & 0 & 0 & 0 & 3 & 3 \\
\hline & $\begin{array}{l}\text { Safety } \\
\text { Concerns }\end{array}$ & 1 & 1 & 0 & 0 & 0 & 0 & 2 & 2 \\
\hline & $\begin{array}{l}\text { Time } \\
\text { Consuming }\end{array}$ & 1 & 0 & 0 & 0 & 0 & 0 & 1 & 1 \\
\hline & $\begin{array}{l}\text { Little } \\
\text { interest in } \\
\text { sport }\end{array}$ & 1 & 0 & 0 & 0 & 0 & 0 & 1 & 1 \\
\hline & $\begin{array}{l}\text { Limits } \\
\text { Friendships }\end{array}$ & 1 & 0 & 0 & 0 & 0 & 0 & 1 & 1 \\
\hline & b-Total & 5 & 4 & 1 & $\mathbf{0}$ & $\mathbf{0}$ & 1 & 11 & 11 \\
\hline \multicolumn{2}{|c|}{ Total Comments } & 23 & 17 & 23 & 19 & 6 & 9 & 98 & $100 \%$ \\
\hline \multicolumn{2}{|c|}{ No Response } & 2 & 4 & 3 & 3 & 0 & 3 & 15 & \\
\hline
\end{tabular}

Source: own study.

Table 4B. Family Support Reported by Students Not Participating in Sport

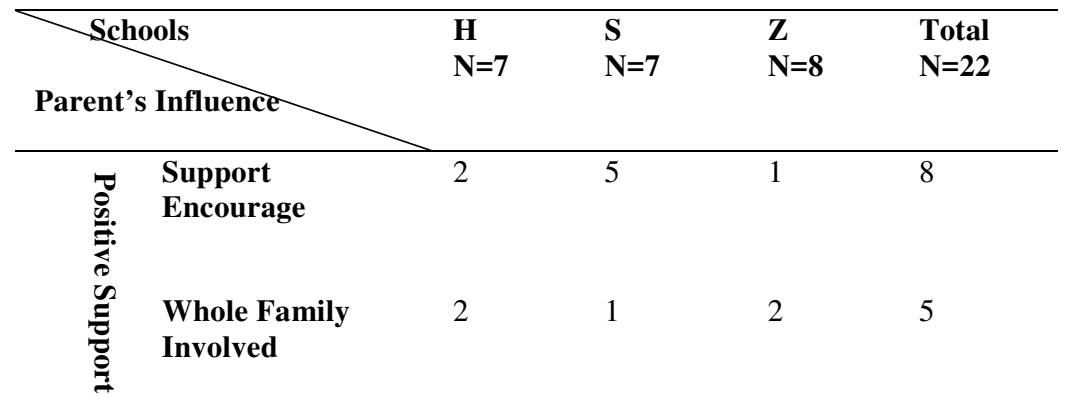

\begin{tabular}{|c|c|c|c|c|c|}
\hline & Parents Proud & 1 & 1 & 1 & 3 \\
\hline \multicolumn{2}{|c|}{ Sub-Total } & 6 & 8 & 5 & 16 \\
\hline \multirow{2}{*}{ 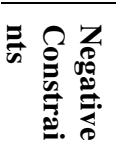 } & No Family Interest & 2 & 1 & 2 & 5 \\
\hline & Financial Burden & & 1 & - & 1 \\
\hline \multicolumn{2}{|c|}{ Sub-Total } & 2 & 2 & 2 & 6 \\
\hline \multicolumn{2}{|c|}{ Total Comments } & 8 & 10 & 7 & 23 \\
\hline \multicolumn{2}{|c|}{ No Response } & - & 1 & 1 & 2 \\
\hline
\end{tabular}

Source: own study.

Note. All respondents in school's B, C \& D participated in sport. 
Sixteen of the 23 comments made by the students who did not play sports also reported positive parental influences. Only three types of support were mentioned; eight spoke of general support and encouragement and three of feelings of pride and approval. Another five mentioned whole family involvement in sport. Of the six comments which represented negative parental constraints, five explained that their family had no interest in sport, while the sixth reported that the respondent's involvement in sport was a financial burden to the family.

\section{Discussion}

The $80 \%(\mathrm{~N}=89)$ rate of sport participation found among the respondents was somewhat higher than the overall rate of $75 \%$ reported in the (Australian Bureau of Statistics 2012) study and the average of 65\% among secondary students reported in SA. The higher rate could be a reflection of the fact that schools $\mathrm{B}, \mathrm{C}$ and $\mathrm{H}$ all had a policy of compulsory sports participation. All the students from these schools $(\mathrm{N}=51=46 \%)$ played sports. The Total Mentions of Sports Played show that most of these students played at least two sports, and at School P, many played three. Those not playing sport all came from Schools H, S and Z, which encouraged but did not enforce participation. Non-participation was greatest in School S, where nine out of 13 respondents were not involved. Approximately seven out of 22 respondents at School Z and six out of 25 at School H played no sport.

Family could be seen to have played a role in these figures on sports participation. Parents who were strongly in favour of their children's involvement in sport ensure that their children attended schools where participation in sport was compulsory, provided that they had the means to do so. Those who gave priority to other activities, such as school studies or music, could have chosen to send their children to schools where sports participation is optional.

The 23 different sports which the students played are consistent with the wide range reported in previous surveys(Australian Bureau of Statistics 2012), and South Australia (Office for Recreation and Sport 2010), although the percentages playing soccer and Australian Rules Football was somewhat higher in this study. Six of the nine most frequently mentioned sports involved team games. Given that a third $(\mathrm{N}=35)$ played a total of 14 different sports, those organising and funding sports would do well to provide a wide range of sporting activities to suit individual needs and interests.

Among those participating in sports, parental influence was seen predominantly in positive terms, $86 \%$ describing various forms of parental support and only $11 \%$ reporting negative constraints. In only $11 \%$ of cases, however, were parents actively involved themselves. The students who did not play sport also reported positive parental support, but mentioned only three of the categories of influence given by students playing sport. Furthermore, the two types of parental negative constraint reported by non-participating students reached a total of six, as compared to the 16 positive comments. Five of these related to the respondents' families having little or no interest in sport. Overall, the proportion of negative constraints to positive support comments among those not playing sport was thus higher than for those who participated in sport. Across all respondents, the most commonly mentioned negative constraint (mentioned six times) was the family's lack of interest in sport.

\section{Conclusions and recommendations}

This in-depth qualitative study confirmed that the majority of the Year 11 respondents from the six schools involved were playing sport. In most instances their participation was being actively encouraged by the school and the family, the two groups that most influenced their lives, socially and culturally. The schools either mandated or actively encouraged the playing of sports. Most parents were seen by their children to have a supportive influence in encouraging and facilitating their sports participation, a finding which supports previous studies on this topic. The range of views expressed by respondents in this qualitative study can be beneficial to teachers and sports co-ordinators in better understanding the students they are dealing with.

This research could be used as a pilot project for the development of a much larger statistical study covering a full cross section of senior secondary students in South Australia, including regional and rural students who were not part of this study. The negative constraints reported by a few respondents also point to 
the need for further in-depth investigation of family support for children's sport among families of particular sub-groups, such as low socio-economic background and newly arrived immigrants.

\section{REFERENCES}

Australian Bureau of Statistics. (2012). Sports and Physical Recreation: A Statistical Overview, Australia, 2012. Canberra, Australia.

Brusted, J.R. (1993). Who will go out and play? Parental and psychological influences on children's attraction to physical activity. Pediatrics Exercise Science, 5(3), 210-223.

Chan, D.K., Lonsdale, C., \& Fung, H.H. (2012). Influences of coaches, parents, and peers on the motivational patterns of child and adolescent athletes. Scandinavian Journal of Medicine \& Science in Sports, 22, 558-568.

Cote, J. (1999). The influence of the family in the development of talent in sport. The Sport Psychologist, 13, 395-417.

Currie, J. (2009). The relationship between sport and children's mental health. Education Connect, 14, 14-15.

Griffin, R.S. (1998). Sports in the lives of children and adolescents: Success on the field and in life. Westport: Praeger.

Hardy, L., Kelly, B., Chapman, K., King, L., \& Farrell, L. (2010). Parental perceptions of barriers to children's participation in organised sport in Australia. Journal of Paediatrics and Child Health, 46, 197-203.

Hesketh, K., Waters, E., Green, J., Salmon, L., \& Williams, J. (2005). Healthy eating, activity and obesity prevention: a qualitative study of parent and child perceptions in Australia. Health Promotion International, 20(1), 19-26.

Independent Sport Panel. (2009). The future of sport in Australia. Canberra: Commonwealth of Australia.

Lee, S. (2009). Adam Scott gets back on course. Retrieved from http://www.dailytelegraph.com.au/news/adam-scottgets-back-on-course/story-e6frewt0-1225796433521

Leff, S.S., \& Hoyle, H.R. (1995). Young athletes' perceptions of parental. Journal of Youth and Adolescence, 24(2), 187203.

Moore, L.L., Lombardi, D.A., White, M.J., Campbell, J.L., Oliveria, S.A., \& Ellison, R.C. (1991). Influence of parents' physical - activity levels on activity levels of young children. The Journal of Pediatrics, 118(2), 215-219.

Nezhad, M., Rahmati, M., \& Nezhad. M. (2012). Relationship between social-economic status of family and adolescents' student sport participation. Scholars research library, 3(8), 4012-4016.

Office for Recreation and Sport. (2010). Trends in Recreation and Sport. Adelaide: Government of South Australia.

Smolicz, J.J., \& Secombe, M.J. (1981). The Australian school through children's eyes. Melbourne: Melbourne University Press.

Smolicz, J.J., \& Secombe, M.J. (1986). Italian language and culture in South Australia: A memoir approach. In C. Bettoni (Ed.), Altro Polo: Italians abroad: Studies on language contacts in English speaking countires (pp. 27-60). Sydney: Frederick May Foundation for Italian Studies: University of Sydney .

Smolicz, J.J., \& Secombe, M.J. (1989). Types of language activation and evaluation in an ethnically plural society. In U. Ammon (Ed.), Status and fuction of language and language varieties (pp. 478-514). Berlin: de Gruyter.

Taylor, T. (2000). Women, sport and ethnicity: Exploring experiences of difference in netball. (Unpublished PhD Thesis), University of New South Wales, Sydney.

Wheeler, S. (2011). The significance of family culture for sports participation. International review for the sociology of sport, 2(47), 235-252.

Wright, J., MacDonald, D., \& Groom, L. (2003). Physical activity and young people: Beyond participation. Sport, Education and Society, 8/1, 17-33.

$\begin{array}{ll}\text { AUTHOR'S ADDRESS: } & \text { Vegneskumar Maniam } \\ & \text { School of Education } \\ & \text { University of New England } \\ & \text { NSW, 2350, Australia } \\ & \text { E-mail: vmaniam@une.edu.au }\end{array}$

Received: 17 September 2017; Accepted: 27 October 2017 